\title{
Ultrastructure of the surface structures and secretory glands of the rosette attachment organ of Gyrocotyle urna (Cestoda: Gyrocotylidea)
}

\author{
Larisa G. Poddubnaya ${ }^{1}$, Tomáš Scholz ${ }^{2,3}$, Roman Kuchta $^{2,3}$, Céline Levron ${ }^{2}$ and David I. Gibson ${ }^{4}$ \\ ${ }^{1}$ Institute of Biology of Inland Waters, Russian Academy of Sciences, 152742 Borok, Yaroslavl Province, Russia; \\ ${ }^{2}$ Institute of Parasitology, Biology Centre of the Academy of Sciences of the Czech Republic and ${ }^{3}$ Faculty of Science, University \\ of South Bohemia, Branišovská 31, 37005 České Budějovice, Czech Republic;
}

${ }^{4}$ Department of Zoology, Natural History Museum, Cromwell Road, London SW7 5BD, UK

Key words: Cestoda, Gyrocotylidea, Gyrocotyle urna, rosette organ, adhesive secretion, secretory glands, ultrastructure

\begin{abstract}
The surface structures and gland cells of the posterior rosette organ of Gyrocotyle urna Grube et Wagener, 1852, a member of the group presumed to be the most basal of the tapeworms (Cestoda: Gyrocotylidea), was studied by scanning electron and transmission electron microscopy. Surface structures on the outer (oriented away from the intestinal wall) and inner (in contact with the intestinal wall) rosette surfaces differ from each other and represent a transitional form between microvilli and microtriches typical of tapeworms (Eucestoda). The inner surface of the rosette possesses numerous glands. On the basis of the size and electron-density of their secretory granules, three types of unicellular gland cells can be distinguished. The least common type (Type I) is characterized by the production of small, round, electron-dense granules of about $0.3 \mu \mathrm{m}$ in diameter, whereas another type of secretion (Type II) is formed from homogenous, moderately electron-dense, spheroidal granules of about $0.7 \mu \mathrm{m}$ in diameter. The most common type of glands (Type III) is recognized by a secretion comprising large, elongate, electron-dense granules of about $1 \mu \mathrm{m}$ long and $0.5 \mu \mathrm{m}$ broad. The secretory granules of the three types of the glands are liberated by an eccrine mechanism and the gland ducts open via small pores on the inner rosette surface. The complex of secretory glands of the posterior rosette of G. urna is similar to those in the anterior attachment glands of monogeneans (as opposed to the types of glands present in other helminth groups). However, the tegumental surface structures of Gyrocotyle are supporting evidence for the relationship between the Gyrocotylidea and Eucestoda.
\end{abstract}

The Gyrocotylidea is a small, enigmatic order of flatworms and includes species that are parasites of ratfishes (Holocephali: Chimaeridae), an ancient group of vertebrates. The Gyrocotylidea is the most basal group of cestodes (Brooks et al. 1985, Ehlers 1985, Gibson 1994, Rohde 1994, Xylander 1986a, 1996, 2001, 2007), which has been unequivocally confirmed by molecular data (Olson et al. 2001, Lockyer et al. 2003, Waeschenbach et al. 2007). Gyrocotylideans are monozoic (contain only a single set of genital organs), unlike most other cestodes which are polyzoic (i.e., with repeated sets of genitalia), and are attached to the spiral valve (intestine) of their host by a posterior rosette organ. With this orientation, gyrocotylideans differ markedly from the remaining cestode groups, the attachment organs of which are situated at the anterior end of the body and play a role in the adhesion of the worm to the host's intestine (Whittington and Cribb 2001).

Little information is available on the glandular system of the rosette attachment organ of adult of specimens of Gyrocotyle Diesing, 1850, the only genus within the order (Gibson 1994). The ultrastructure of the rosette tegument and its glands in adult worms was studied by Lyons (1969), who reported the rosette tegument to be covered with bifurcate microvilli and that glands of a single type are present on the inner surface of the rosette. Later, Allison (1980) indicated the presence of different types of microvilli on the outer and inner rosette surfaces of Gyrocotyle rugosa Diesing, 1850. The fine structure of the anterior glands of the larva (lycophore) of G. urna Grube et Wagener, 1852 was studied more recently by Xylander (1990), who described four types of glands differing in the size and structure of their secretory granules.

The opinion on the relationships between gyrocotylideans and other members of the Neodermata has been controversial. The Gyrocotylidea was recognized as a group with affiliation to both monogeneans and cestodes by some authors (Bychowsky 1957, Llewellyn 1965, 1986, Malmberg 1974). On the other hand, most recent studies, including those inferred from molecular data, indicate that gyrocotylideans are basal cestodes (Brooks et al. 1985, Ehlers 1985, Gibson 1994, Rohde 1994, Xylander 1986a, 1996, 2001, 2007, Olson et al. 2001, Lockyer et al. 2003, Waeschenbach et al. 2007).

Ultrastructural observations of the surface of G. urna have revealed the presence of microtriches, thus providing additional support for the inclusion of the gyro- 
cotylideans in the Cestoda (Xylander 1986b, 2001, 2007, Poddubnaya et al. 2006). Because of the basal position of the Gyrocotylidea in the tree of the Cestoda and the still problematical evolution of the neodermatan groups in general, ultrastructural investigations of this group may provide important data useful for phylogenetic studies. The present study provides new information on the ultrastructure of the secretory glands of the rosette organ of $G$. urna together with observations on the surface structure of the rosette folds.

\section{MATERIALS AND METHODS}

Specimens of Gyrocotyle urna were removed from the spiral valve of a rabbit fish, Chimaera monstrosa L., caught in the North Sea off Bergen, Norway in October 2005 by R. Kuchta. The worms were fixed entire using $5 \%$ glutaraldehyde in $0.1 \mathrm{M}$ sodium cacodylate buffer $(\mathrm{pH} 7.2)$ for 40 days at $5^{\circ} \mathrm{C}$, rinsed 4 times for $20 \mathrm{~min}$ in the same buffer and postfixed in $1 \%$ osmium tetroxide for $1 \mathrm{~h}$. The material was then dehydrated in a graded series of alcohol and acetone, and embedded in Araldite and Epon. Ultrathin sections were stained with uranyl acetate and lead citrate, and examined using JEM 1010 and JEM 1011 transmission electron microscopes operating at $80 \mathrm{kV}$. For scanning electron microscopical observations, fixed tapeworms were dehydrated in a graded ethanol series with a final change in absolute ethanol, and then critical-pointdried with liquid $\mathrm{CO}_{2}$. The specimens were mounted on stubs, sputter-coated with gold-palladium and examined using LEO1420 and JEOL-7401F scanning electron microscopes operating at $15 \mathrm{kV}$.

\section{RESULTS}

The posterior attachment organ of the body of Gyrocotyle urna has a cavity, the funnel, the distal border of which has a folded wall, forming a rosette. The two sides of irregular folds of the rosette wall are referred to as the inner and outer surfaces. The inner surface is directed towards the intestinal wall of the host during attachment, and the outer surface is directed towards the lumen of the intestine.

\section{SEM investigation of the rosette surfaces}

Fig. 1

The rosette organ of $G$. urna possesses numerous folds (Fig. 1a, d, e). Between these folds, eggs may be observed (Fig. 1a). In SEM images, the inner surface of the rosette folds bears numerous small, dome-shaped protuberances (c. $2.5 \mu \mathrm{m}$ in diameter), which, like the remainder of the tegument, are covered by densely packed surface structures (Fig. 1b, c). At a greater magnification (Fig. 1c), open pores and numerous minute granules can be seen surrounding the dome-shaped protuberances. The outer rosette surface lacks the latter features (Fig. 1f).

\section{Epithelial surfaces of the rosette}

Fig. 2

The syncytial distal cytoplasm of the outer and inner surfaces of the rosette can be distinguished by differences in their glandular nature and surface structures
(Fig. 2a). The syncytial cytoplasm of the outer surface is c. $2.2 \mu \mathrm{m}$ thick and filled with electron-lucent oval vesicles, dark rod-shaped bodies and mitochondria (Fig. 2b). The distal cytoplasm lies on a thin basal lamina with an underlying fibrous matrix and is connected to the epithelial cell bodies lying beneath narrow longitudinal and circular muscle layers (Fig. 2a, b). This epithelium bears dense, regularly arranged surface structures which are lanceolate in shape and c. $350 \mathrm{~nm}$ long. Along the surface membrane of the basal region (100 $\mathrm{nm}$ in length and $90 \mathrm{~nm}$ in diameter) of these structures is a thin deposit of a dark material, and the distal region (c. $250 \mathrm{~nm}$ of the length) contains electron-dense material (Fig. 2c, d).

The epithelial lining of the inner surface of the rosette is c. $2.3 \mu \mathrm{m}$ thick. The dense cytoplasm contains the same kind of rod-shaped and vesicular inclusions as the outer side, and the same kind of underlying basal lamina with fibrous matrix occurs beneath the syncytial cytoplasm (Fig. 2e, f). However, better-developed circular and longitudinal muscle layers are on the inner side of the folds (Fig. 2f). The external surface of the epithelial cytoplasm is covered with digitiform structures, the total length of which is c. $440 \mathrm{~nm}$ by $180 \mathrm{~nm}$ in width. Distally, these structures are not tapered but bi- or tridentate (Fig. 2e, g). Their cylindrical base contains distal tegumental cytoplasm surrounded and supported by a thin, dense layer present beneath the plasma membrane (Fig. 2e, g). Two or three (depending on the number of the distal 'teeth') additional longitudinal rods of dense material may also be observed in the basal region in both longitudinal and cross-sections (Fig. 2e, g). The dense material of these formations unites to form a dense apex to the conical 'teeth' (Fig. $2 \mathrm{~g}$ ). The ventral epithelial wall of the folds is perforated by a large number of the gland ducts with three distinctive kinds of secretion (Figs. 2a, 3a, b, 4a, 5a).

\section{Type I rosette gland cells}

Fig. 3

This type occurs infrequently (Fig. 3a). Every unicellular secretory gland, excluding its duct, is enclosed by an irregularly folded plasma membrane and localised in the central parenchymal region of the folds (Fig. 3c). The cell nucleus contains a nucleolus and a number of small areas of chromatin embedded in nucleoplasm. The granular endoplasmic reticulum (GER), in the form of enlarged cisternae and Golgi complexes, occupies the perinuclear region (Fig. 3c, g). Small, spherical, dense granules are scattered in the cell cytoplasm (Fig. 3c, g). Each granule is bounded by a membrane and contains a fine, dense material and measures c. $0.3 \mu \mathrm{m}$ in diameter (Fig. 3e, g). The cell body tapers distally to form a narrow extension close to the epithelial cytoplasm that continues as the secretory duct (Fig. 3a, d). The duct cytoplasm is filled with secretory granules (Fig. 3d). Near the terminal end of the duct a single row of microtubules appears within the duct cytoplasm close to its plasma membrane (Fig. 3e, f). The pyriform terminal 

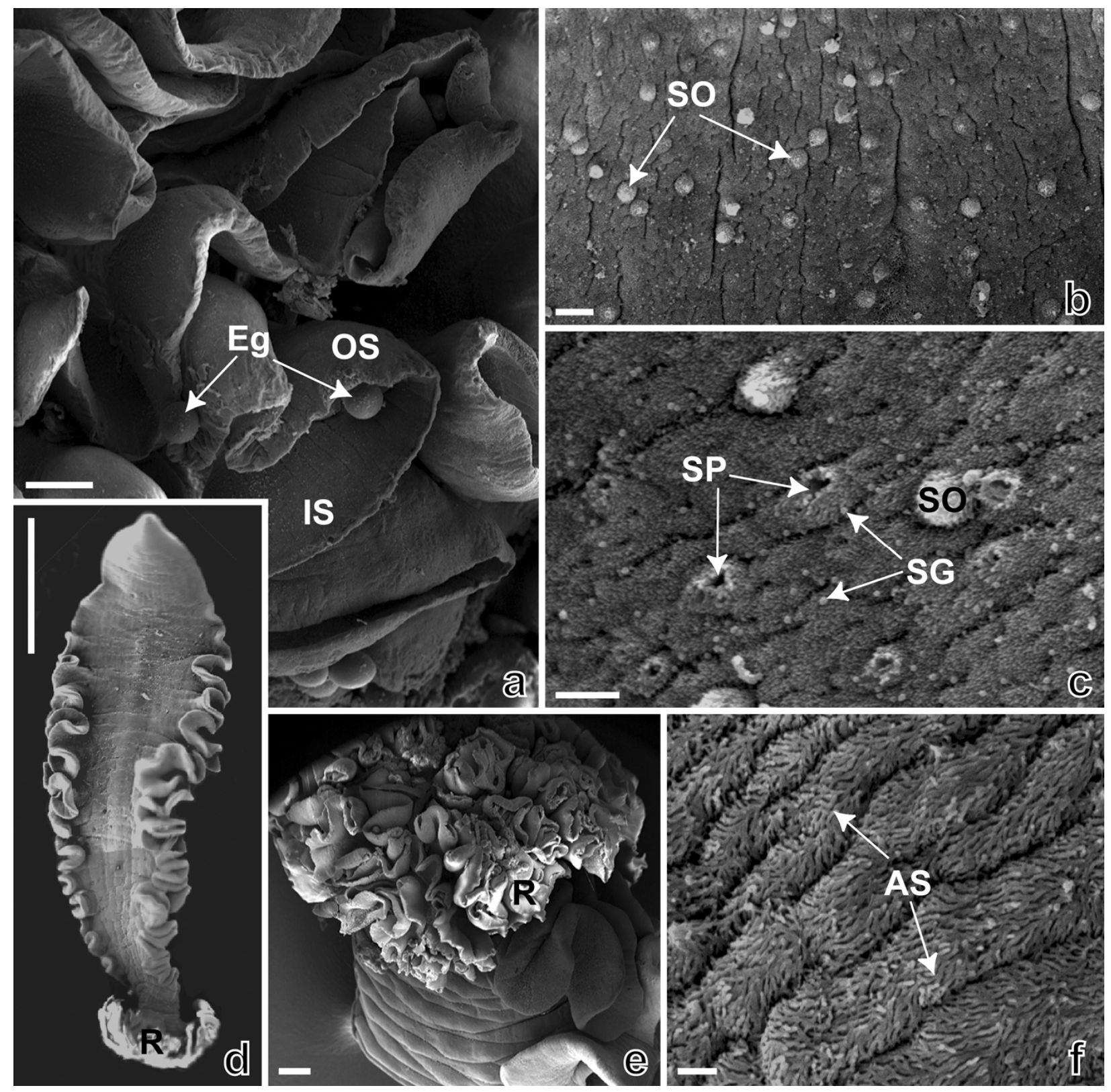

Fig. 1. Scanning electron micrographs of the rosette of Gyrocotyle urna. a - region of the rosette folds, showing their outer and inner surfaces, with visible eggs between the folds; $\mathbf{b}$ - region of the inner surface of the folds covered by elevated, dome-shaped protuberances of secretory openings; $\mathbf{c}$ - inner surface of the folds showing both closed secretory openings and open secretory pores with secretory granules between them; $\mathbf{d}$ - the worm body with the rosette at the posterior end; $\mathbf{e}$ - rosette organ comprising numerous folds; $\mathbf{f}$ - outer surface of the rosette covered with surface structures. Abbreviations: AS - apical tegumental structures; Eg - eggs; IS - inner rosette surface; OS - outer rosette surface; R - rosette; SG - secretory granules; SO - closed secretory openings; SP - secretory pores. Scale bars: $\mathrm{a}=100 \mu \mathrm{m} ; \mathrm{b}=4 \mu \mathrm{m} ; \mathrm{c}, \mathrm{f}=1 \mu \mathrm{m} ; \mathrm{d}=10 \mathrm{~mm} ; \mathrm{e}=200 \mu \mathrm{m}$.

end of the duct passes through the epithelial cytoplasm. The ducts terminate in pores that are attached to tegumental tissues by desmosomal contact (Fig. 3f).

\section{Type II rosette gland cells}

Fig. 4

Type II glands are characterized by the production of homogenous, spheroidal, moderately electron-dense granules c. $0.7 \mu \mathrm{m}$ in diameter (Fig. $4 \mathrm{a}, \mathrm{c}, \mathrm{g}$ ). Cell bodies are situated in the rosette fold midway between the dorsal and ventral surfaces and are distinguished by a thin layer of perinuclear cytoplasm around the nucleus and a GER and Golgi region associated with moderately dense, spheroidal inclusions and electron-lucent vesicles (Fig. 4c). This type of gland cell body possesses extensions filled with homogenous cytoplasm within which solitary secretory granules and vesicles are observed (Fig. 4a, b, d) as well as extensions filled with only 

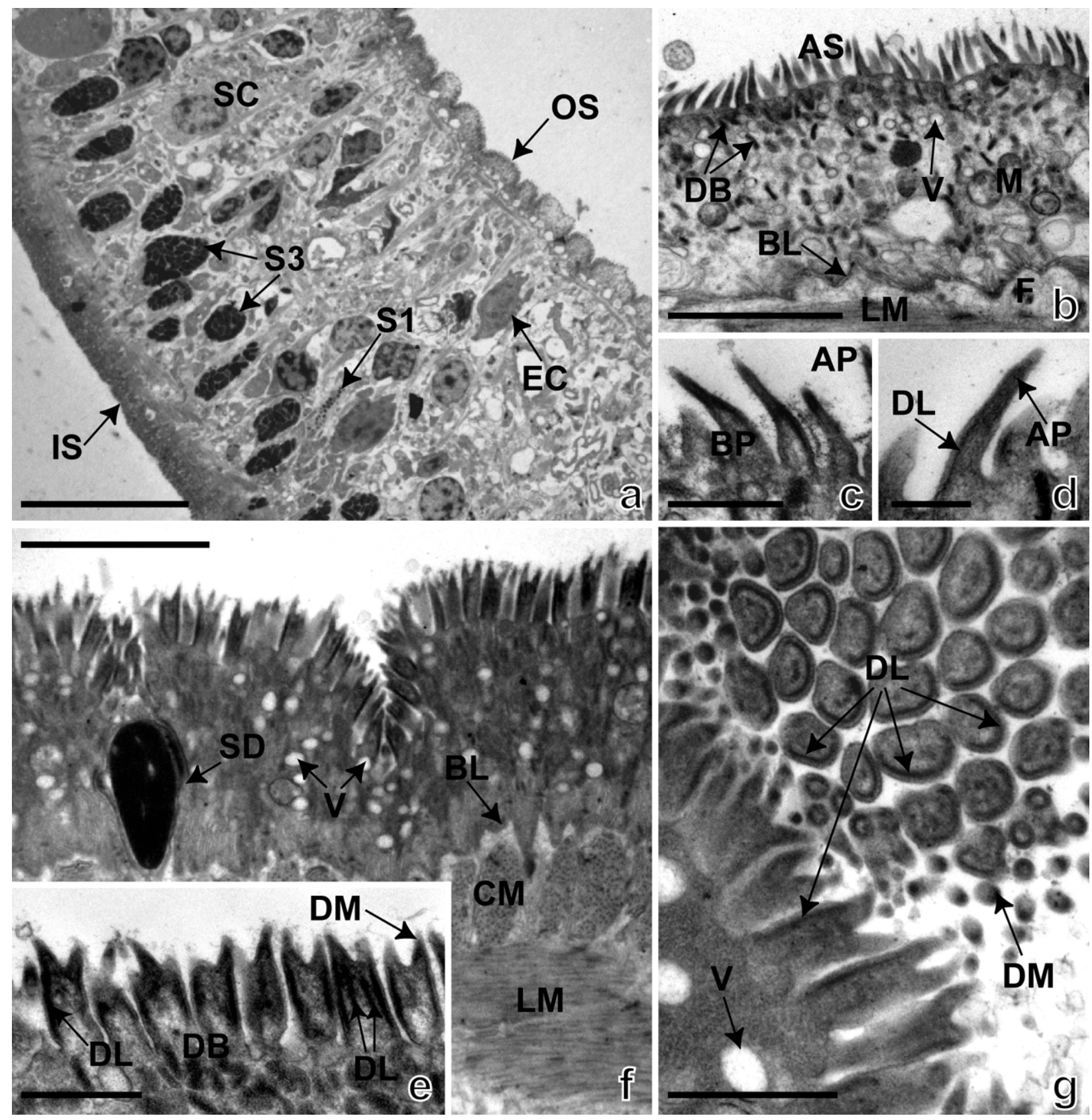

Fig. 2. Transmission electron micrographs of the epithelial surfaces of the rosette folds of Gyrocotyle urna. a - section through the rosette fold; note the location of the secretory ducts close to the inner rosette surface and the outer rosette surface free from any secretory apparatus; $\mathbf{b}$ - epithelial lining of the outer surface; $\mathbf{c}, \mathbf{d}$ - surface structures covering the outer surface, showing their electron-dense distal extremities; $\mathbf{e}$ - surface structures on the inner surface, showing their bi- or tri-dentate distal extremities; $\mathbf{f}$ - epithelial lining of the inner surface; $\mathbf{g}$ - longitudinal and cross-sections of surface structures on the inner surface. Abbreviations: AP - apical part of the surface structures of the rosette; AS - apical structures on the outer surface of the rosette; $\mathrm{BL}$ basal layer; BP - proximal portion of the surface structures of the rosette; CM - circular muscles; DB - dense bodies; DL - support rods of the proximal part of surface structures of the ventral rosette surface; DM - dense material of the bi- or tri-dentate distal extremities; EC - epithelial cyton; F - fibrous matrix; IS - inner rosette surface; LM - longitudinal muscles; $\mathrm{M}$ - mitochondria; OS - outer rosette surface; SC - secretory cyton; SD - secretory duct; S1 - secretion of Type I glands; S3 - secretion of Types III glands; V - vesicles. Scale bars: $\mathrm{a}=20 \mu \mathrm{m} ; \mathrm{b}, \mathrm{f}=2 \mu \mathrm{m} ; \mathrm{c}, \mathrm{d}=0.2 \mu \mathrm{m} ; \mathrm{e}, \mathrm{g}=0.5 \mu \mathrm{m}$. 

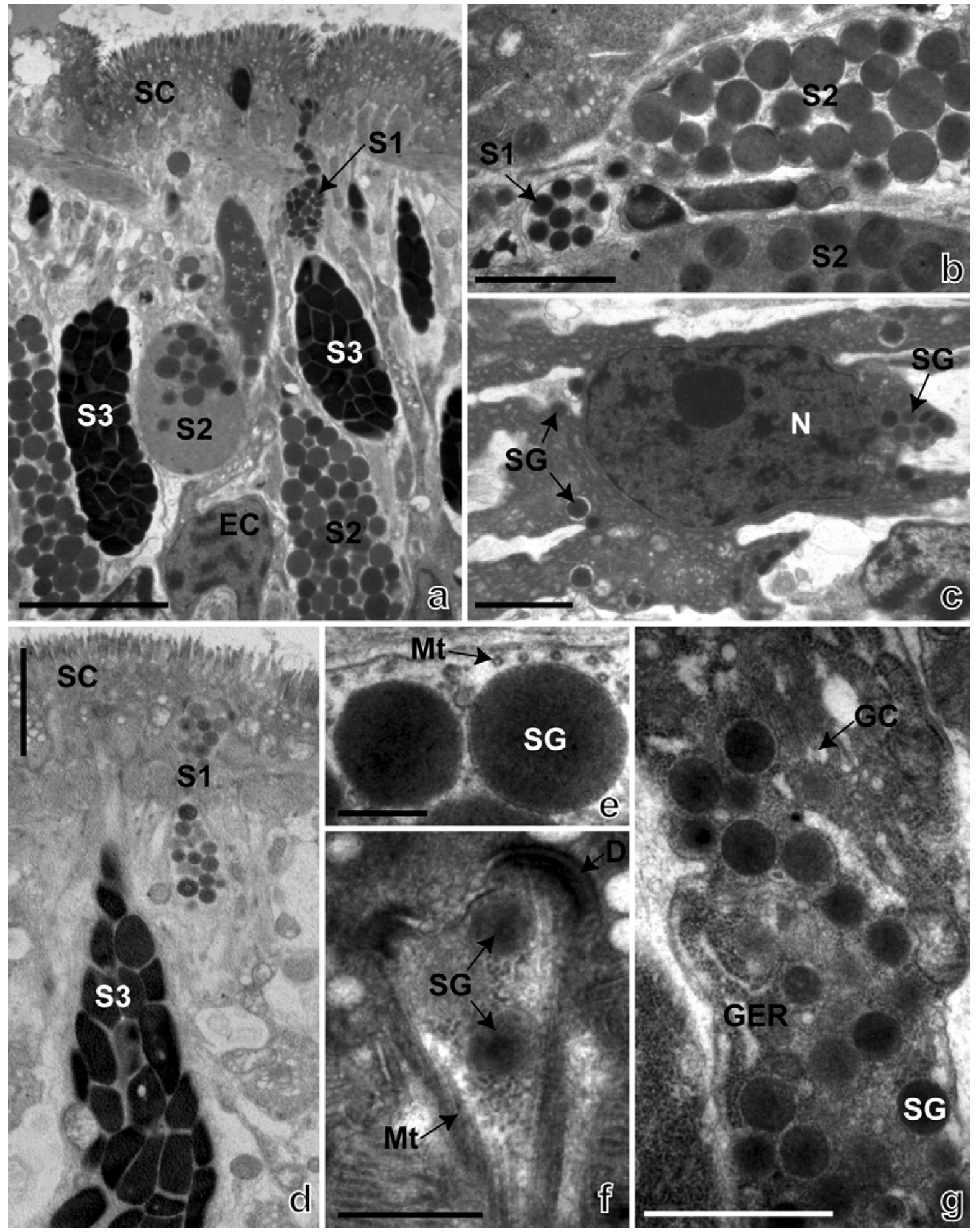

Fig. 3. Type I secretory glands of the rosette organ of Gyrocotyle urna. a - three kinds of secretion beneath the inner epithelial lining; b - two different kinds of spheroidal secretory granules; $\mathbf{c}$ - the cell body of a Type I gland; d - the duct of a Type I gland with its distal region penetrating the epithelial syncytial cytoplasm; e - S1 type granules within the duct lined by peripheral microtubules; $\mathbf{f}$ - the terminal region of the gland duct of S1 type granules showing peripheral microtubules and desmosomal contact between the duct and the epithelial cytoplasm; $\mathbf{g}$ - part of the perinuclear cytoplasm of the cell body of Type I glands with round granules. Abbreviations: D - desmosomal contact; EC - epithelial cyton; GC - Golgi complex; GER - granular endoplasmic reticulum; $\mathrm{Mt}$ - microtubules; $\mathrm{N}$ - nucleus; SC - syncytial cytoplasm; SG - secretory granules; S1, S2, S3 - secretion of Type I, II, III glands, respectively. Scale bars: $\mathrm{a}=5 \mu \mathrm{m} ; \mathrm{b}-\mathrm{d}=2 \mu \mathrm{m} ; \mathrm{e}=0.2 \mu \mathrm{m} ; \mathrm{f}=0.5 \mu \mathrm{m} ; \mathrm{g}=1 \mu \mathrm{m}$. 
loosely packed secretory granules (Fig. 4g). In the cytoplasm of the terminal region of both types of glandular extensions, peripheral microtubules are found and the terminal region of the secretory duct is held in place attached to the internal lining of the epithelial cytoplasm by a circular septate desmosome (Fig. 4e, f). The liberation of secretory products (granules and vesicles) is realized by the rupture of the duct plasma membrane which extends across the pore (Fig. 4e, g).

\section{Type III rosette gland cells}

Fig. 5

The ventral surface of the folds is perforated by a large number of gland ducts with tightly packed large electron-dense granules that have an angular appearance as a result of their compression within the duct cytoplasm (Fig. 5a-c). These large individual secretory granules were also observed outside the folds (Fig. 5a, b), having been voided into the space between the ventral surfaces of two folds. The secretory ducts extend from the cell bodies localised in the parenchymal region of the folds. Small round secretory droplets appear to be formed in Golgi complexes of the perinuclear cytoplasm of the glands. Within the surrounding cytoplasm they fuse to form dense, elongate secretory granules of c. 1 $\mu \mathrm{m}$, but up to $1.7 \mu \mathrm{m}$, in length and c. $0.5 \mu \mathrm{m}$ in diameter. The granules are transported through distal extensions of the gland cells that function as ducts which penetrate the epithelial layer (Fig. 5b, c). The ducts taper in the region of the epithelium and become constricted, forming a neck through which secretory granules pass (Fig. 5b, c). Microtubules line the terminal region of the duct (Fig. 5e). The gland pore is attached to the surrounding cytoplasm of the epithelial wall by a septate desmosome, which is underlaid by an electrondense collar within the duct cytoplasm (Fig. 5d, e). At high magnification, cross-sections of this type of secretion show that the granules contain a rough, fibrillar material (Fig. 5e).

\section{DISCUSSION}

The present and previous ultrastructural studies on the posterior attachment organ, the rosette organ, of Gyrocotyle species have shown that both inner and outer surfaces of the rosette folds bear two different kinds of apical structures (Lyons 1969, Allison 1980, present study). The rosette tegument differs from that of the remainder of the body, which is covered by filiform microtriches possessing a short electron-dense distal spine and a basal plate between their distal and proximal regions; these microtriches are small $(0.7 \mu \mathrm{m}$ in length and c. $0.06-0.08 \mu \mathrm{m}$ in breadth) and uniform in shape (Xylander 1986b, 2001, Poddubnaya et al. 2006). Hence, these filiform microtriches from the body surface of $G$. urna are identical in structure with those found on the surface of all groups of the Eucestoda, and their presence supports the extensive phylogenetic data indicating the inclusion of the gyrocotylideans within the Cestoda (Ehlers 1985, Xylander 2001, 2007, Lockyer et al. 2003, Olson and Tkach 2005).

Unlike the microtriches on the body surface of Gyrocotyle, there is a specialisation of the surface structures on the rosette folds. The rosette surface structures may be considered as transitional forms between microvilli and cestode microtriches; this suggestion is based on observations of microvilli in larval tapeworms (Kuperman 1988, Poddubnaya 1995, Xylander 2001, Tyler and Hooge 2004).

The present TEM study shows that there are three types of unicellular secretory glands, thus differing from the observations of Lyons (1969), who described only one type (our Type III). The three types of the glands can be distinguished by their secretory granules. The least common type (Type I) is characterized by the production of small, round, electron-dense granules of about $0.3 \mu \mathrm{m}$ in diameter, whereas the second type of secretion (Type II) is formed from homogenous, moderately electron-dense, spheroidal granules of about 0.7 $\mu \mathrm{m}$ in diameter. The most common type of gland (Type III) is recognized by a secretion comprising large, elongate, electron-dense granules of about $1 \mu \mathrm{m}$ long and $0.5 \mu \mathrm{m}$ broad. Due to the presence of the same type of mechanism for the liberation of glandular products, it is not possible to determine which type of gland cell forms the dome-shaped structures visible in SEM images of the ventral surface.

It should be noted that the presence of two or three different types of specialised secretory glands, with a secretion comprising rod-shaped and spheroidal granules and an eccrine release mechanism, have also been found in the anterior adhesive areas of some monogene-

Fig. 4. Type II secretory glands of the rosette of Gyrocotyle urna. a - secretory ducts beneath the ventral epithelial layer, showing both the ducts and enlarged extensions of the gland-cells filled with spheroidal, moderately dense secretory granules; $\mathbf{b}-$ cell body of Type II glands, with enlarged extensions containing solitary spheroidal granules; c - region of the perinuclear cytoplasm containing extensive GER, Golgi complexes and associated spheroidal granules; $\mathbf{d}$-broad extension of a gland cell with its distal region penetrating the epithelial layer; note the presence of spheroidal granules and numerous vesicles within the cytoplasm of the extension; $\mathbf{e}$ - the voiding of vesicles from the distal extremity of the extension/duct after penetrating the epithelial cytoplasm; $\mathbf{f}$ - distal extremity of secretory duct beneath the surface plasmalemma, showing spheroidal granules and vesicles within the duct cytoplasm and desmosomal contact between the duct and the epithelial cytoplasm; $\mathbf{g}$ - the secretory ducts of Type II, with loosely packed spheroidal granules, and Type III, with tightly packed elongate granules. Abbreviations: D - desmosomal contact; Ex - gland-cell extension; GC - Golgi complex; GER - granular endoplasmic reticulum; Mt - microtubules; $\mathrm{N}$ - nucleus; SC - syncytial cytoplasm; SD - secretory duct; SG - secretory granules; S2, S3 - secretion of Type II, III glands, respectively; TE - terminal extremity; $\mathrm{V}$ - vesicles. Scale bars: $\mathrm{a}=10 \mu \mathrm{m} ; \mathrm{b}, \mathrm{e}, \mathrm{g}=2 \mu \mathrm{m} ; \mathrm{c}, \mathrm{f}=1 \mu \mathrm{m} ; \mathrm{d}=5 \mu \mathrm{m}$. 


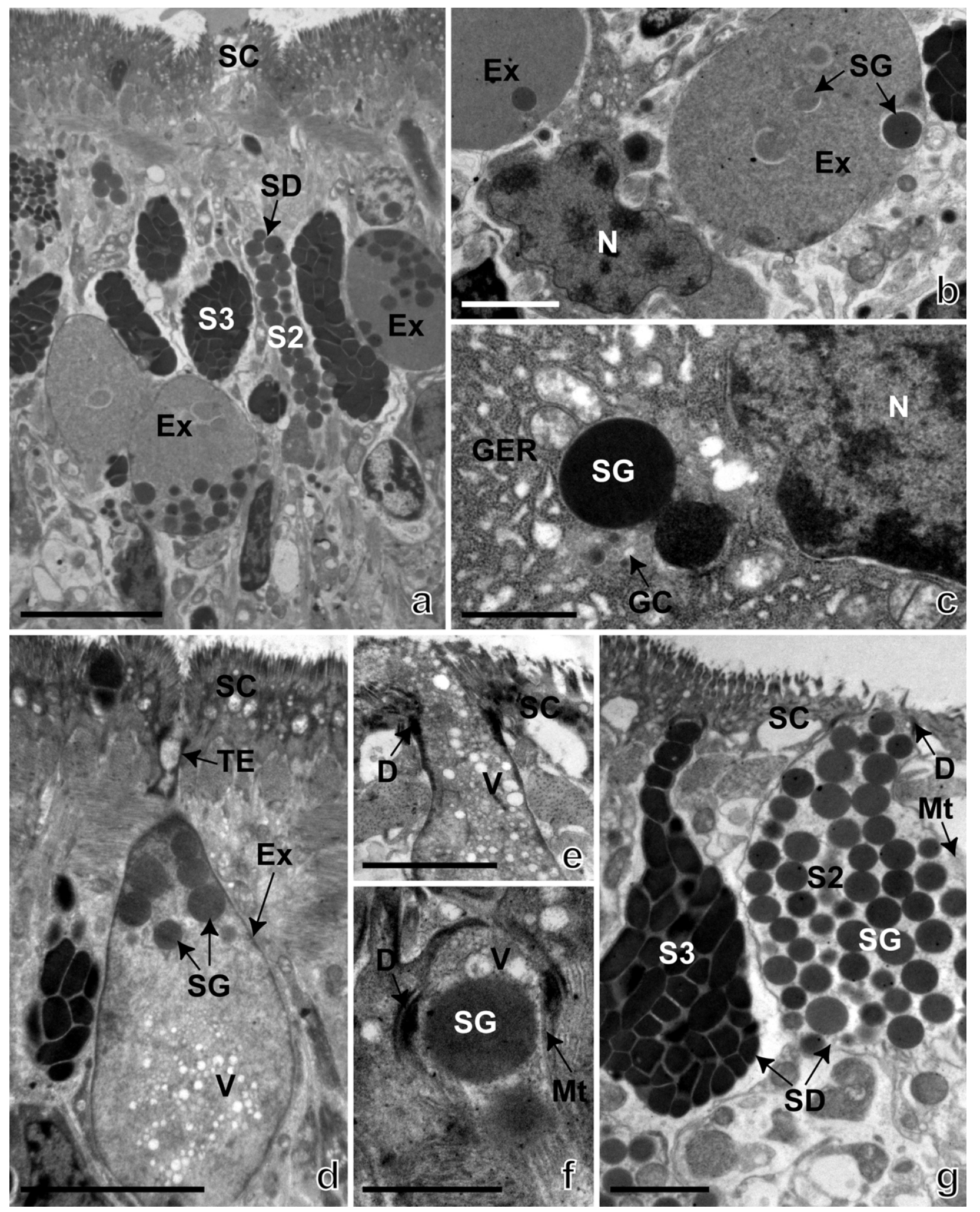


ans, where it is supposed that the secretion of these glands aids the temporary attachment of the worms to the host tissues (Kritsky 1978, El-Naggar and Kearn 1980, 1983, Rees and Kearn 1984, Kearn et al. 1995, Cribb et al. 1997, 1998, Kearn and Evans-Gowing 1998, Whittington and Cribb 1998, 1999, 2001, Hamwood et al. 2002, Whittington et al. 2004). In addition, experimental studies have shown that abundant large, tubular secretory granules of monogeneans form an adhesive material and that the spheroidal secretions function in the severance of attachment and may also play a role in preparing the host tissue for attachment by displacing host mucus present on this surface (El-Naggar and Kearn 1983, Cribb et al. 1997, Hamwood et al. 2002, Whittington et al. 2004). In the anterior attachment glands of monogeneans, long, tubular (or rod-shaped) secretory granules are always more abundant in secretions than spherical ones (Whittington et al. 2000). The present TEM study of the glands of G. urna has demonstrated that large, elongate secretory granules are more numerous than spheroidal ones, thus exhibiting some similarity with the situation in monogeneans.

Numerous large, rod-shaped granules, apparently forming the adhesive secretion (see above), are composed of a protein in all monogeneans (Whittington et al. 2000, Hamwood et al. 2002). Moreover, Lyons (1969) provided histochemical evidence that the large, elongate granules of $G$. urna (the secretion of the Type III glands) also contain a PAS-positive material, probably an adhesive mucoprotein. Taking into account a direct correlation between different modes of secretion and similarities in the form and quantities of the secretory granules in monogeneans and Gyrocotyle, it can be speculated that the abundant large, elongate secretion of the Gyrocotyle rosette (from the Type III glands) is the adhesive one and that the spheroidal secretion of the rosette (from the Type I and II glands) serves to dissolve the adhesive secretion during detachment when the worm needs to move. The rosette organ of G. urna attaches to the mucosal surface of the spiral valve of chimaeroid fishes, establishing a strong suction pressure when its funnel aperture is attached to the valve wall (Halvorsen and Williams 1967). A series of waves of contraction passes from the margin of the rosette towards the aperture of the funnel during the attachment process of the rosette and enables the worm to move to another area of the spiral valve (Watson 1911, Halvorsen and Williams 1967).

The glandular nature of the rosette organ of G. urna does exhibit some differences from the frontal (or scolex) glands of the apparently more closely related Eucestoda. As a rule, only one or two kinds of secretory glands associated with the anterior attachment organ are found in adult eucestodes; these possess different mechanisms (apocrine, eccrine, microapocrine or tumu- logenesis) for the discharge of their secretory products. For example, the members of the order Caryophyllidea possess two types of secretory glands with apocrine and eccrine mechanisms for voiding their rod-shaped and rounded electron-dense secretory granules (Richards and Arme 1981, Davydov and Poddubnaya 1988, Poddubnaya et al. 2003). Two types of glands with eccrine and apocrine (or tumulogenesis) mechanisms have been noted for the release of the spheroidal and rounded osmiophilic secretory granules of the order Bothriocephalidea (Kuperman and Davydov 1982, Diaz-Castaneda et al. 1995, Žd’árská and Nebesářová 1997, Poddubnaya et al. 2007). An apocrine mechanism for the discharge of secretory gland cells producing electron-dense, spheroidal granules has been observed in the Cyclophyllidea (Kuperman and Davydov 1982, Stoitsova et al. 1997). Nevertheless, ultrastructural observations of species of the orders Diphyllobothriidea, Proteocephalidea, Tetraphyllidea and Trypanorhyncha have revealed one or two types of anterior glands possessing only eccrine mechanisms for the release of a secretion comprising rounded electron-dense granules (Andersen 1975, Coggins 1980, Kuperman and Davydov 1982, McCullough and Fairweather 1989, Žd'árská and Nebesářová 1999, Bruňanská et al. 2000, Žd'árská et al. 2004). It should be mentioned that the predominant secretions of the anterior glands in adult cestodes are glycoproteins (Davydov and Mikryakov 1988, Davydov and Poddubnaya 1988, McCullough and Fairweather 1989, Stoitsova et al. 1997).

In the case of adult digeneans, the adhesive glands are associated with suckers (Whittington and Cribb 2001). Ultrastructurally, only one type of specialised gland cells has been revealed in two trematode genera, Haplometra and Opisthioglyphe, by Halton and Dermott (1967); the secretion of these cells is a mucopolysaccharide. One type of unicellular glands with an eccrine mechanism for the discharging of their secretion has been described for the adhesive lappets of strigeoid trematodes of the genera Cyathocotyle and Apatemon by Erasmus $(1969,1970)$. In this context, it should be mentioned that it has recently been suggested that the Trematoda may be more closely related to the cestodes than monogeneans (Park et al. 2007). The attachment organ of aspidogastreans also produces only a single type of spherical electron-dense granules, as observed in Aspidogaster conchicola by Halton and Lyness (1971), but two types of secretions (protein and mucopolysaccharide) were found in Aspidogaster limacoides by Timofeeva (1972). A single type of unicellular secretory gland, containing two kinds of granules, associated with the anterior proboscis of adults of the cestode order Amphilinidea has been described by Davydov and Kuperman (1993) and Xylander (2001). Another type of anterior secretion, which has a syncytial structure and 

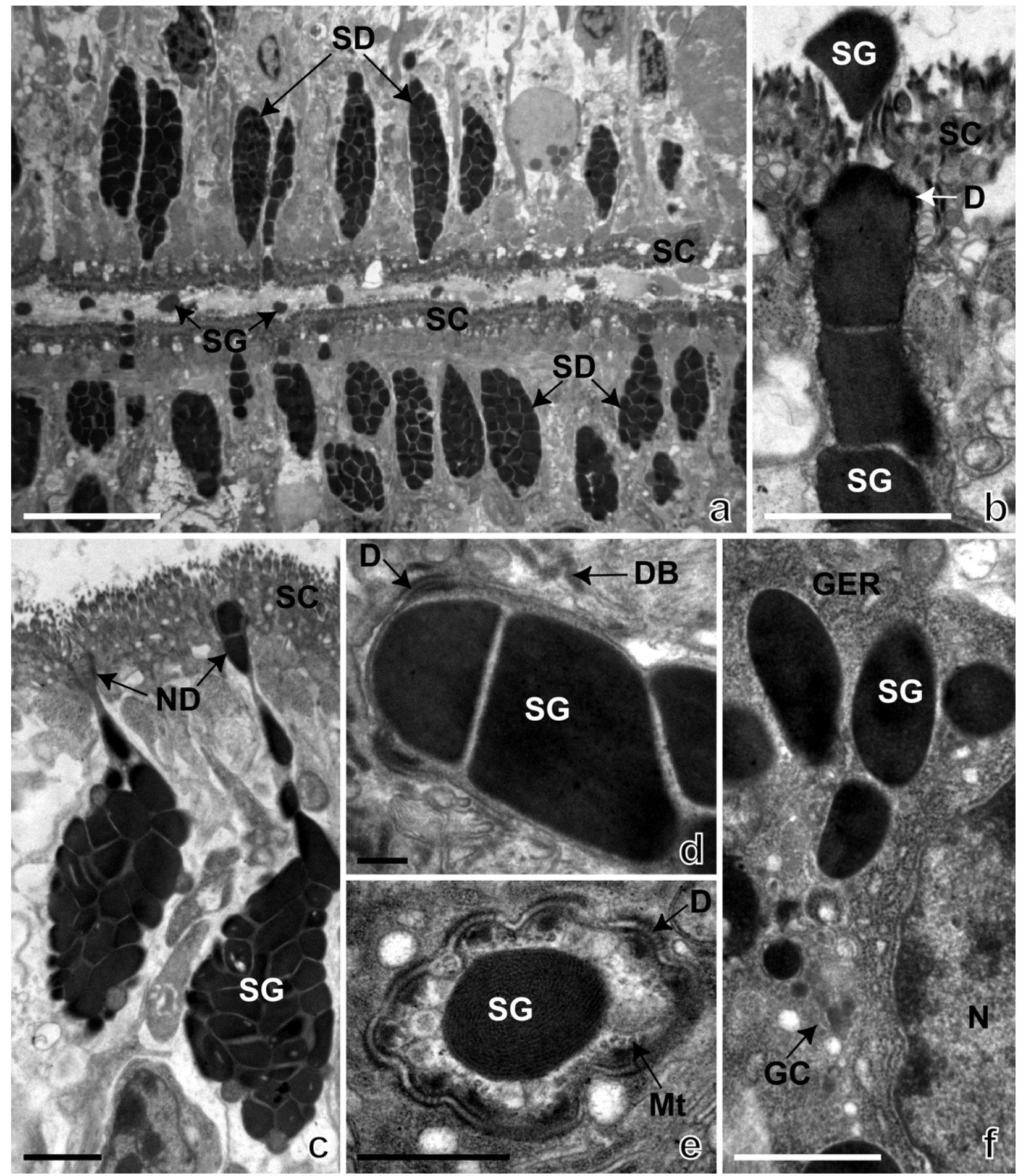

Fig. 5. Type III secretory glands of the rosette of Gyrocotyle urna. a - section of two inner surfaces of the folds, showing the numerous glandular ducts filled with a dark, tightly packed secretion; note the different phases of duct penetration of the epithelial layer of both ventral surfaces and the free secretory granules in the lumen between folds; $\mathbf{b}$ - the voiding of secretory granules from the duct penetrating the epithelial cytoplasm; c - two secretory ducts tapering towards the epithelial lining and with a constriction which forms a neck; $\mathbf{d}$ - the distal extremity of a secretory duct connected to the epithelial cytoplasm by desmosomal contact; $\mathbf{e}$ - cross-section of a duct within the epithelial cytoplasm showing a ring-shaped desmosome; $\mathbf{f}-$ region of perinuclear cytoplasm of the gland-cell body, producing elongate, electron-dense granules. Abbreviations: D - desmosomal contact; DB dense bodies; GER - granular endoplasmic reticulum; GC - Golgi complex; Mt - microtubules; N - nucleus; ND - neck of the secretory duct; SC - syncytial epithelial cytoplasm; SD - secretory ducts; SG - secretory granules. Scale bars: $\mathrm{a}=10 \mu \mathrm{m} ; \mathrm{b}, \mathrm{c}=$ $2 \mu \mathrm{m} ; \mathrm{d}, \mathrm{f}=1 \mu \mathrm{m} ; \mathrm{e}=0.5 \mu \mathrm{m}$. 
an apocrine (or microapocrine) release mechanism for secretory granules, is also present in the latter group (Poddubnaya, unpublished data).

A comparative analysis of the glandular secretion of the rosette of adult $G$. urna with those of anterior secretions of larvae (lycophores) of the same species (Xylander 1990) indicates a similarity in the form of two types of glands (Types I and II). However, larval glands of the Neodermata degenerate following the infection of the first host, and secretory glands are formed again de novo in the postlarval stages and are not related to the larval ones (Kearn 1971, Dubinina 1974, Kuperman and Davydov 1981, 1982, Kuperman 1988, Xylander 1990, Whittington and Cribb 2001, Swiderski and Mackiewicz 2004).

In conclusion, the similarity between the secretory glands of the posterior rosette of G. urna and those in the anterior attachment glands of monogeneans (as opposed to the types of glands present in other helminth groups) may support conclusion that the Monogenea may be the sister group of Gyrocotylidea. At the same time, the tegumental surface structures of Gyrocotyle are supporting evidence for the close relationship between the Gyrocotylidea and Eucestoda. From the phylogenetic point of view, it is important to mention that both these characteristics of Gyrocotyle support the suggestion of an intermediate evolutionary position of the Gyrocotylidea between the Monogenea and Cestoda and within the Cercomeromorphae, thus, supporting the ideas by Bychowsky (1957), Llewellyn (1965, 1986) and Malmberg (1974), but are in contrast to more recent views (e.g., Lockyer et al. 2003, Park et al. 2007).

Acknowledgements. The authors are grateful to G.A. Bristow, University of Bergen, Norway, for the possibility to collect material in the North Sea. The present study was undertaken as a part of a joint bilateral research programme of scientific exchange and cooperation between the Russian and Czech Academies of Science. L.G.P. was supported during 2007 by the American Society for Parasitology Boris Kuperman Memorial Fund. This study was supported by the Grant Agency of the Czech Republic (projects 524/07/P039 and $524 / 08 / 0885)$ and research projects of the Institute of Parasitology (Z60220518, LC 522).

\section{REFERENCES}

ALLISON F.R. 1980: Sensory receptors of the rosette organ of Gyrocotyle rugosa. Int. J. Parasitol. 10: 341-353.

ANDERSEN K. 1975: Ultrastructural studies on Diphyllobothrium ditremum and D. dendriticum (Cestoda, Pseudophyllidea), with emphasis on the scolex tegument and the tegument in the area around the genital atrium. Z. Parasitenkd. 46: 253-264.

BroOKS D.R., O'GRADY R.T., GLEN D.R. 1985: The phylogeny of the Cercomeria Brooks, 1982 (Platyhelminthes). Proc. Helminthol. Soc. Wash. 52: 1-20.

BRUŇANSKÁ M., FAGERHOLM H.P., GUSTAFFSON M.K.S. 2000: Ultrastructural studies of Proteocephalus longicollis (Cestoda, Proteocephalidea): transmission electron microscopy of scolex glands. Parasitol. Res. 86: 717-723.

BYCHOWSKY B.E. 1957: [The Monogenea, Their Systematics and Phylogeny.] AN SSSR, Moscow-Leningrad, 509 pp. (In Russian.)

CoGgINS J.R. 1980: Tegument and apical end organ fine structure in the metacestode and adult Proteocephalus ambloplitis. Int. J. Parasitol. 10: 409-418.

CRIBB B.W., WhitTINGTON I.D., Chisholm L.A. 1997: Observations on ultrastructure of the anterior adhesive areas and other anterior glands in the monogenean, Monocotyle spiremae (Monocotylidae), from the gills of Himantura fai (Dasyatididae). Int. J. Parasitol. 27: 907-917.

CRIBB B.W., WhitTINGTON I.D., CHISHOLM L.A. 1998: Observations on ultrastructure of the anterior adhesive areas and other anterior gland cells in the monogenean Merizocotyle australensis (Monocotylidae), from the nasal fossae of Himantura fai (Dasyatididae). Microsc. Res. Tech. 42: 200-211.

DAVYDOV V.G., KUPERMAN B.I. 1993: The ultrastructure of the tegument and the peculiarities of the biology of Amphilina foliacea (Plathelminthes: Amphilinidea). Folia Parasitol. 40: $13-22$.

DAVYDOV V.G., MIKRYAKOV V.R. 1988: [Adaptive structures of body covering of some cestodes associated with protection of parasites from action of the host organism.] Trudy GELAN 36: 88-100. (In Russian.)
DAvydov V.G., PodDuBnaya L.G. 1988: [Functional morphology of the frontal and uterine glands in cestodes of the order Caryophyllidea.] Parazitologiya 22: 449-257. (In Russian.)

DiAZ-CASTANEDA V., CARABEZ-TREJO A., LAMOTHE-ARGUMEDO R. 1995: Ultrastructure of the pseudophyllidean cestode Bothriocephalus acheilognathi, parasite of freshwater fish of commercial importance. An. Inst. Biol., UNAM, Ser. Zool., 66: $1-16$.

DUBININA M.N. 1974: [The development of Amphilina foliacea at all stages of the life cycle and the position of Amphilinidea in the system of Plathelminthes.] Parazitol. Sb., Zool. Inst. Akad. Nauk SSSR, 26: 9-28. (In Russian.)

EHLERS U. 1985: Phylogenetic relationship within the Platyhelminthes. In: S. Conway Morris, J.D. George, R. Gibson and H.M. Platt (Eds.), The Origin and Relationships of Lower Invertebrates. Oxford Univ. Press, Oxford, pp. 143-158.

EL-NAGGAR M.M., KEARN G.C. 1980: Ultrastructural observations on the anterior adhesive apparatus in the monogeneans Dactylogyrus amphibothrium Wagener, 1857 and D. hemiamphibothrium Ergens, 1956. Z. Parasitenkd. 61: 223-241.

EL-NAGGAR M.M., KEARN G.C. 1983: Glands associated with the anterior adhesive areas and body margins in the skin-parasitic monogenean Entobdella soleae. Int. J. Parasitol. 13: 67-81.

ERASMUS D.A. 1969: Studies on the host-parasite interface of strigeoid trematodes. IV. The ultrastructure of the lappets of Apatemon gracilis minor Yamaguti 1933. Parasitology 59: 193-201.

ERASMUS D.A. 1970: The host-parasite interface of strigeoid trematodes. VII. Ultrastructural observations on the adhesive organ of Diplostomum phoxini Faust, 1918. Z. Parasitenkd. 33: $211-224$.

GIBSON D.I. 1994: Order Gyrocotylidea Poche, 1926. In: L.F. Khalil, A. Jones and R.A. Bray (Eds.), Keys to the Cestode Parasites of Vertebrates. CAB International, Wallingford, UK, pp. 11-13.

HALTON D.W., DERMOTT E. 1967: Electron microscopy of certain gland cells in two digenetic trematodes. J. Parasitol. 53: 1186-1191. 
HALTON D.W., LYNESS R.A.W. 1971: Ultrastructure of the tegument and associated structures of Aspidogaster conchicola (Trematoda: Aspidogastrea). J. Parasitol. 57: 1198-1210.

HALVORSEN O., WILliams H.H. 1967: Studies of the helminth fauna of Norway. IX. Gyrocotyle (Platyhelminthes) in Chimaera monstrosa from Oslo Fjord, with emphasis on its mode of attachment and a regulation in the degree of infection. Nytt Mag. Zool. 15: 130-142.

Hamwood T.E., CribB B.W., Halliday J.A., Kearn G.C., WHITTINGTON I.D. 2002: Preliminary characterisation and extraction of anterior adhesive secretion in monogenean (platyhelminth) parasites. Folia Parasitol. 49: 39-49.

KEARN G.C. 1971: The attachment of ancyrocephalid monogenean Haliotrema balisticus to the gills of the trigger fish, Balistes capriscus. Parasitology 63: 157-162.

KEARN G.C., EVANS-GOWING R. 1998: Attachment and detachment of the anterior adhesive pads of the monogenean (platyhelminth) parasite of Entobdella soleae from the skin of the common sole (Solea solea). Int. J. Parasitol. 28: 1583-1593.

KEARN G.C., WhitTINGTON I.D., Evans-Gowing R. 1995: Use of cement for attachment in Neocalceostomoides brisbanensis, a calceostomatine monogenean from the gill chamber of the blue catfish, Arius graeffei. Int. J. Parasitol. 25: 299-306.

KRITSKY D.C. 1978: The cephalic glands and associated structures in Gyrodactylus eucaliae Ikezaki and Hoffman 1957 (Monogenea: Gyrodactylidae). Proc. Helminthol. Soc. Wash. 45: 37-49.

KUPERMAN B.I 1988: Functional Morphology of Lower Cestodes. Nauka, Leningrad, 166 pp. (In Russian.)

KUPERMAN B.I., DAVYDOV V.G. 1981: The fine structure of glands in oncospheres, procercoids and plerocercoids of Pseudophyllidea (Cestoidea). Int. J. Parasitol. 12: 135-144.

KUPERMAN B.I., DAVYDOV V.G. 1982: The fine structure of frontal glands in adult cestodes. Int. J. Parasitol. 12: 285-293.

LLEWELLYN J. 1965: The evolution of parasitic platyhelminths. In: A.E.R. Taylor (Ed.), Evolution of Parasites. Third Symposium of the British Society for Parasitology, Blackwell Scientific Publications, Oxford, pp. 47-78.

LLEWELLYN J. 1986: Phylogenetic inference from platyhelminth life-cycle stages. In: M.J. Howell (Ed.), Parasitology - quo vadit? Proceedings of the Sixth International Congress of Parasitology, Brisbane, Australian Academy of Sciences, Canberra, pp. 281-289.

LOCKYER A.E., OLSON P.D., LITTLEWOOD D.T.J. 2003: Utility of complete large and small subunit rRNA genes in resolving the phylogeny of the Neodermata (Platyhelminthes): implications and a review of the cercomer theory. Biol. J. Linn. Soc. 78: $155-171$.

LYONS K.M. 1969: The fine structure of the body wall of Gyrocotyle urna. Z. Parasitenkd. 33: 95-109.

MALMBERG G. 1974: On the protonephridial system of Gyrocotyle and the evolution of Cercomeromorphae (Platyhelminthes). Zool. Scr. 3: 65-81.

MCCUlLOUGH J.S., FAIRWEATHER I. 1989: The fine structure and possible function of scolex gland cells in Trilocularia acanthiaevulgaris (Cestoda, Tetraphyllidea). Parasitol. Res. 75: 575-582.

OLSON P.D., LiTTLEWOOD D.T.J., BRAY R.A., MARIAUX J. 2001 Interrelationships and evolution of the tapeworms (Platyhelminthes: Cestoda). Mol. Phylogen. Evol. 19: 443-467.

OLSON P.D., TKACH V.V. 2005: Advances and trends in the molecular systematics of the parasitic Platyhelminthes. Adv. Parasitol. 60: 165-243

PARK J.-K., KIM K.H., KANG S., KIM W., EOM K., LiTTLEWOOD D.T.J. 2007: A common origin of complex life cycles in parasitic flatworms: evidence from the complete mitochondrial genome of Microcotyle sebastis (Monogenea: Platyhelminthes). BMC Evol. Biol. 7: 11-24.

PODDUBNAYA L.G. 1995: [Peculiarities of the integument genesis in procercoids of caryophyllidean cestodes.] Parazitologiya 29: 13-18. (In Russian.)

PODDUBNAYA L.G., BRUŇANSKÁ M., KUCHTA R., SCHOLZ T. 2006: First evidence of the presence of microtriches in the Gyrocotylidea. J. Parasitol. 92: 703-707.

PodDUBNAYA L.G., MACKIEWICZ J.S., KUPERMAN B.I. 2003: Ultrastructure of Archigetes sieboldi (Cestoda: Caryophyllidea): relationship between progenesis, development and evolution. Folia Parasitol. 50: 275-292.

Poddubnaya L.G., SchOlZ T., LeVRON C., KuCHTA R., GibSON D.I. 2007: Frontal glands in the pseudoscolex of Paraechinophallus japonicus (Yamaguti, 1934) (Cestoda, Bothriocephalidea, Echinophallidae). Acta Parasitol. 52: 325-334.

REES J.A., KEARN G.C. 1984: The anterior adhesive apparatus and an associated compound sense organ in the skin-parasitic monogenean Acanthocotyle lobianchi. Z. Parasitenkd. 70: 609-625.

RICHARDS K.S., ARME C. 1981: The ultrastructure of the scolexneck syncytium, neck cells and frontal gland cells of Caryophyllaeus laticeps (Caryophyllidea: Cestoda). Parasitology 83: 477-487.

ROHDE K. 1994: The origins of parasitism in the Platyhelminthes. Int. J. Parasitol. 24: 1099-1115.

Stoitsova S.R., GeORgIEV B.B., DacheVA R.B., Vinarova M.I. 1997: Scolex glands associated with the rostella in three species of the Dilepididae (Cestoda: Cyclophyllidea). Acta Zool. 78: 187-193.

SWIDERSKI Z., MACKIEWICZ J.S. 2004: Ultrastructural studies on the cellular organisation of the coracidium of the cestode Bothriocephalus clavibothrium Ariola, 1899 (Pseudophyllidea, Bothriocephalidae). Acta Parasitol. 49: 116-139.

TIMOFEEVA T.A. 1972: [Glandular system of adhesive disc in Aspidogaster limacoides (Trematoda: Aspidogastrea).] Zool. Zh. 51: 1071-1073. (In Russian.)

TYLER S., HOOGE M. 2004: Comparative morphology of the body wall in flatworms (Platyhelminthes). Can. J. Zool. 82: 194210.

WAESCHENBACH A., Webster B.L., BRAY R.A., LitTLEWOOD D.T.J. 2007: Added resolution among ordinal level relationship of tapeworms (Platyhelminthes: Cestoda) with complete small and large subunit nuclear ribosomal RNA genes. Mol. Phylogen. Evol. 45: 311-325.

WATSON E.E. 1911: The genus Gyrocotyle, and its significance for problems of cestode structure and phylogeny. Univ. Calif. Publ. Zool. 6: 353-468.

WhitTington I.D., ARMSTRONG W.D., CRIBB B.W. 2004: Mechanism of adhesion and detachment at the anterior end of Neoheterocotyle rhinobatidis and Troglocephalus rhinobatidis (Monogenea: Monopisthocotylea: Monocotylidae). Parasitol. Res. 94: 91-95.

WhitTINGTON I.D., CRIBB B.W. 1998: Glands associated with the anterior adhesive areas of the monogeneans, Entobdella sp. and Entobdella australis (Capsalidae) from the skin of $\mathrm{Hi}$ mantura fai and Taeniura lymma (Dasyatididae). Int. J. Parasitol. 28: 653-665.

WhitTington I.D., CRiBB B.W. 1999: Morphology and ultrastructure of the anterior adhesive areas of the capsalid monogenean parasites Benedenia rohdei from the gills and B. lutjani from the pelvic fins of Lutjanus carponotatus (Pisces: Lutjanidae). Parasitol. Res. 85: 399-408.

WhitTINGTON I.D., CRIBB B.W. 2001: Adhesive secretions in the Platyhelminthes. Adv. Parasitol. 48: 101-223. 
WhitTington I.D., CRiBB B.W., Hamwood T.E., Halliday J.A. 2000: Host-specificity of monogenean (platyhelminth) parasites: a role for anterior adhesive areas? Int. J. Parasitol. 30: 305-320.

XYLANDER W.E.R. 1986a: Ultrastrukturelle Befunde zur Stellung von Gyrocotyle im System der parasitischen Plathelminthen Verh. Dtsch. Zool. Ges. 79: 193.

XYLANDER W.E.R. 1986b: Zur Biologie und Ultrastruktur der Gyrocotylida und Amphilinida sowie ihre Stellung im phylogenetischen System der Plathelminths (Platyhelminthes). Dissertation, Universität Göttingen, 307 pp.

XYLANDER W.E.R. 1990: Ultrastructure of lycophora larva of Gyrocotyle urna (Cestoda, Gyrocotylidea). IV. The glandular system. Zoomorphology 109: 319-328

XYLANDER W.E.R. 1996: Neodermata. In: W. Westheide and R.M. Rieger (Eds.), Spezielle Zoologie, Teil 1: Einzeller und Wirbellose. Gustav Fisher Verlag, Stuttgart, New York, pp. 230-258.

Received 1 April 2008
XYLANDER W.E.R. 2001: The Gyrocotylidea, Amphilinidea and the early evolution of Cestoda. In: D.T.J. Littlewood and R.A. Bray (Eds.), Interrelationships of the Platyhelminthes. Taylor \& Francis, London, pp. 103-111.

XYLANDER W.E.R. 2007: Neodermata. In: W. Westheide and R.M. Rieger (Eds.), Spezielle Zoologie, Teil 1: Einzeller und Wirbellose Tiere. 3rd Edition. Gustav Fisher Verlag, Stuttgart, New York, pp. 233-260.

ŽĎÁRSKÁ Z., NEBESÁŘOVÁ J. 1997: Ultrastructure of three types of scolex gland cells in adult Bothriocephalus claviceps (Cestoda: Pseudophyllidea). Folia Parasitol. 44: 139-146.

ŽĎÁRSKÁ Z., NEBESÁŘOVÁ J. 1999: Distribution and ultrastructure of two types of scolex gland cells in adult Proteocephalus macrocephalus (Cestoda: Proteocephalidea). Parasite 6: 4956.

ŽĎÁRSKÁ Z., SCHOLZ T., NEBESÁŘOVÁ J. 2004: Ultrastructure of the apical glandular region of the scolex of Proteocephalus torulosus (Cestoda: Proteocephalidae). Folia Parasitol. 51: 333-338.

Accepted 12 July 2008 